\title{
Crop diversification for sustainable management of two spotted mite (Tetranychus urticae koch) of jasmine (Jasminum sambac L.)
}

\begin{abstract}
A field trial was conducted to study the influence of crop diversification through intercropping on the incidence of two spotted mite, Tetranychus urticae of jasmine (Jasminum sambac). The results revealed the significant reduction in incidence of the pest in intercropped treatments over monocrop of jasmine. Marigold recorded significantly lowest mean incidence of two spotted mites ( 12.33 no's / $2 \mathrm{~cm}^{2}$ of leaf area), followed by gingelly ( 12.53 no's $\left./ 2 \mathrm{~cm}^{2}\right)$ and cowpea $\left(13.99\right.$ no's $\left./ 2 \mathrm{~cm}^{2}\right)$, with jasmine as sole crop recorded highest two spotted mite incidence $\left(17.73 \mathrm{no}\right.$ 's $\left./ 2 \mathrm{~cm}^{2}\right)$. The highest per cent reduction of two spotted mites over control was noticed in jasmine intercropped with marigold (30.45 per cent) followed by jasmine intercropped with onion (29.32 per cent). Among the intercrops tried, higher incidence of two spotted mite was recorded in jasmine intercropped with fennel $\left(15.26\right.$ no's. $\left./ 2 \mathrm{~cm}^{2}\right)$ and fenugreek $\left(15.13\right.$ no's $\left./ 2 \mathrm{~cm}^{2}\right)$. Jasmine intercropped with marigold recorded 30.67 percent reduced two spotted mite incidence than sole jasmine crop. The population of natural enemies viz., the coccinellid, Stethorus rani, chrysopid, Chrysoperla zastrowi sillemi, and predatory bugs Geocoris pallens, Orius sp. were more recorded in marigold intercropped jasmine with a mean population of 8.70,3.60, 4.40 and 5.30 no's/ five plants respectively. Moreover, the predatory thrips, Scolothrips sexmaculatus was more encountered in jasmine intercropped with marigold (4.30 no's/ $\mathrm{cm}^{2} /$ five plants) than sole jasmine crop. The predatory mites, Neoseiulus longispinosus (2.60 no's/five plants) and Euseius sp (3.60 no's $/ \mathrm{cm}^{2} /$ five plants) were more noticed in jasmine plants intercropped with marigold. The pest defender ratio was highest in jasmine + marigold (1:3.50) and the order falls as jasmine+coriander (1:3.05) and jasmine+gingelly (1:2.34). The chemical profile of marigold flower and leaf extracts were analysed in GC-MS, which contributed 43 and 33 compounds respectively. Allyl iso thiocyanate, linalool, caryophyllene, beta myrcene, tumerone, D-limanone and trans beta ocimene were the compounds of interest present, of which, linalool, beta farnesene, alpha farnesene, allyl isothiocyanate and caryophyllene were present in marigold leaves also. The study indicated the supremacy of marigold in reducing the incidence of the two spotted mite as well as attracting more natural enemy population, bagging the credit of eco-feast crop.
\end{abstract}

Keywords: diversification, intercropping, two spotted mite, Tetranychus urticae, marigold, natural enemies
Volume 3 Issue 2 - 2019

\author{
I Merlin Kamala \\ Department of Agricultural Entomology, Tamil Nadu Agricultural \\ University, India
}

Correspondence: I Merlin Kamala, Department of Agricultural Entomology, Tamil Nadu Agricultural University,

Coimbatore-641003, India, Email merlinento@gmail.com

Received: October 24, 2018 | Published: April 04, 2019

\section{Introduction}

Jasmine (Jasminum sambac L.) is traditionally as well as commercially cultivated for its sweet-scented flowers all over the world. Globally, jasmine is celebrated in many countries as their national flower and utilized as decoration for ceremonies and rituals as an important part of cultural heritage. Flowers and un opened buds are used for making garlands, bouquets, in religious and ceremonial functions, perfumed hair oils, attars, soaps, wine and drinks. ${ }^{1}$ The area and production of total flowers in India were increasing impressively over the years. The world production of jasmine concrete is around 20 tonnes per annum, out of which India is producing and exporting about 2 tonnes. ${ }^{2}$ The largest area under jasmine cultivation is in Tamil Nadu and Karnataka from where it is distributed to metropolitan cities. ${ }^{3}$ The production of jasmine is affected by various factors, among which, insect pests are the most devasting factor. The major pests affecting jasmine are jasmine bud worm (Hendecasis duplifascialus Hampson), blossom midge (Contarinia maculipennis Felt), leaf webworm (Nausinea geometralis Guenee), gallery worm (Elasmopalpus jasminophagus Hampson), leaf roller, (Glyphodes unionalis Hubner), and the two spotted mite (Tetranychus urticae Koch). Of these, two spotted mite has attained the status of a major pest causing severe economic loss by reducing the vitality of the plants, thereby reducing the productivity of flowers. Tetranychus urticae Koch commonly known as two-spotted mite is a species of plant-feeding mite that is generally considered as pest. It is the most widely known member of the family Tetranychidae or spider mites. Spider mites are named so because many members of this family produce silk webbing on the host plants. In jasmine, flowering commences during March-April and comes to peak in May-July. During this period, the weather is too hot and is favourable for multiplication and so the population increases rapidly. These tiny eight-legged arthropods lay eggs on the underside of leaves. An adult female can lay more than 100 eggs in three weeks. Eggs hatch in four to five days and the entire life cycle from egg to adult is completed in one to three weeks, depending on the temperature. The life-cycle of T. urticae consists of five different stages such as egg, larva, protonymph, deutonymph and adult. Mites are typically found on the underside of leaves, but may colonise entire plants during outbreaks. The mites suck sap from cells on the underside of plant leaves, in the early stages and characteristic white 
speckles can be seen from the upper leaf surface. As mite number increases, these white speckles also increase and the leaf exhibits a bleached appearance. ${ }^{4}$ In case of severe infestation, the whole plant becomes pale in colour, and affects production and size of the flower buds. Damage to the leaves inhibits photosynthesis, and severe infestations can result in premature leaf fall, shoot dieback, and decreased plant vigor. Although the individual lesions are very small, attack by hundreds or thousands of spider mites can cause thousands of lesions and thus can significantly reduce the photosynthetic capability of plants (Zhang 2003). Such buds fetch a low market price. Silk webbing on the undersides of leaves are characteristic signs of spider mites. Under high population densities, the mites move to the tip of the leaf or top of the plant and congregate using strands of silk to form a ball-like mass, which will be blown by winds to new leaves or plants, in a process known as "ballooning'.

As the infestation by the two spotted mite, T. urticae and the jasmine leaf webber, Nausinoe geometralis Guenee coincides with the flushing stage, the silky foliage of jasmine is severely affected, and thereby photosynthetic efficiency of plant is affected and hence affects flower production. The rapid developmental rate, short generation time, and high net reproductive rate of $T$. urticae allows them to achieve damaging population levels very quickly when growth conditions are suitable, resulting in an equally rapid decline of host plant quality.

Jasmine farmers were forced to undertake frequent sprays of pesticides to control the pests. Indiscriminate and injudicious uses of conventional insecticides for managing this pest have been causing different environmental hazards including resurgence, resistance and residue problems (Nalini and Kumar, 2016). Disproportionate usage of chemicals caused health hazards, outbreaks of secondary pests, environmental pollution, objectionable pesticide residues, resources degradation and adverse effect on non-target organisms, and reduction in biodiversity of natural enemies (Balasubramani and Swamiappan, 1993). Therefore, there is an urgent need to use safe but effective, biodegradable pesticides with no or less toxic effects on beneficial organisms.

In search of safer alternatives to chemicals considering their negative impacts, attention has been focused on exploration of diversified cropping system approaches, which is based on the principle of reducing pest incidence by increasing natural enemy activity through diversifying crop ecosystem. Diversification in agriculture is defined as diversion of a sizable acreage from the existing crop system to some alternative crops or cropping systems or farm enterprises. ${ }^{5}$ Intercropping is the agronomic practice of growing two or more crops in the same field at the same time. It is growing of two or more crops in close proximity to promote beneficial interactions between them (Andrews and Kassam, 1976). Intercropping is found to bring reduction of pest populations in the main crop principally in three ways, by delaying the onset of pest incidence, by inhibiting pest build up above ETL and finally increasing the abundance of natural enemies.

Farooq et al. $^{6}$ indicated that some plants contained organic substances that act as pest repellent which keeps insects away from the crops and avoid potential damage. Diverse nature of plants not only obstructs the adults from egg laying but also the release of volatile allelochemicals from a crop deters the adult insect from damaging the crops. Intercropping is one of the important cultural practices in pest management for reducing insect pests by increasing the diversity of an eco-system. ${ }^{7}$ Lakshminarayanan et al..$^{8}$ investigated the intercropping of leguminous vegetables in a pruned field of jasmine (Jasminum sambac L.) and indicated that intercropping pruned jasmine with double rows of vegetable cowpea (Vigna unguiculata) fetched the highest equivalent yield of jasmine $\left(5,393 \mathrm{Kg} \mathrm{ha}^{-1}\right)$ land equivalent ratio (1.99), net returns (Rs. 1, 44,113 ha- $\mathrm{ha}^{-1}$ ) and benefit-cost ratio (3:1) with minimal pest incidence. Anburani and Priyadharshini ${ }^{9}$ explored the intercropping system with mullai (Jasminum auriculatum) and recorded the highest number of productive shoots per plant, flower yield per plant, flower yield per hectare and profitability in the mullai intercropped with cowpea trial and recorded minimum incidence of pests. Intercropping in jasmine ecosystem for pest management has not been experimented yet. Therefore, the present study was undertaken to explore and assess the influence of intercropping on the infestation of jasmine bud worm and the occurrence of natural enemies.

\section{Materials and methods}

A field experiment was conducted during July-November, 2015 at farmer's holding in Manjampati, Madurai. The experiment was carried out in a randomized block design (RBD) and each treatment was replicated thrice. Seeds of the intercrops were sown in a young jasmine plantation of two-year-old crop. All the standard package of practices recommended for the crops was followed except plant protection measures. Nine intercropping systems were evaluated as detailed below:

1. Jasmine + Cowpea (Vigna unguiculata L.) (Co2)

2. Jasmine+Black gram (Vigna mungo L.) (Local)

3. Jasmine+Cluster bean (Cymopsis tetragonolaba L.) (Local)

4. Jasmine+Coriander (Coriandrum sativum) (Local)

5. Jasmine+Fenugreek (Trigonella foenumgraecum L.) (Local)

6. Jasmine+Gingelly (Sesamum indicum L.) (Local)

7. Jasmine+Fennel (Foeniculum vulgare L.) (Local)

8. Jasmine+Onion (Allium cepa L.) (Local)

9. Jasmine+Marigold (Tagetes erecta L.) (Local)

\section{Jasmine pure crop}

The intercropping system was planted at 4:1ratio with recommended spacing. ${ }^{10}$ Observations on per cent infestation of two spotted mite, T. urticae and its their natural enemies in five randomly selected jasmine plants in each intercropping system and jasmine pure crop were recorded from flowering stage at ten days interval.

For assessing the mite incidence, five plants were randomly selected and three leaves per plant representing top, middle and bottom of the plants was selected for sampling. The leaves were brought to the laboratoty and was observed under stero zoom microscope for population of mite and eggs $/ 2 \mathrm{~cm}^{2}$ of leaf area. The data on incidence was transformed to $\sqrt{\mathrm{x}}+0.5$ and analyzed by randomized block design. The treatment mean values of the experiment were compared using Latin Square Distribution (LSD).

\section{Pest: Defender ratio (P: D ratio)}

The defender to pest ratio per cropping system was calculated for each plot by dividing the total number of defenders per cropping system by the total number of pests per cropping system. Total number of pests and natural enemies observed by sweep net and in situ counts 
will be used for estimating P: D ratio ${ }^{11}$

\section{Total no. of defenders}

$\mathrm{P}: \mathrm{D}$ ratio $=$ Total no. of pests

\section{Results}

Intercropping is one of the important cultural practices in pest management for reducing insect pests by increasing the diversity of an ecosystem. ${ }^{7}$

\section{Incidence of two spotted mite in intercropping system}

The crop diversification studies in jasmine ecosystem revealed that the incidence of T. urticae was significantly lower with a mean incidence of 15.37 per cent in jasmine intercropped with marigold (4:1), whereas jasmine as sole crop recorded highest two spotted mite incidence (22.17 per cent) (Table 1$)$. The per cent incidence recorded in jasmine intercropped with marigold were 24.37, 17.36, $12.34,10.23,13.57$ and 14.36 per cent on $20,30,40,50,60$ and 70 days after sowing. The mean incidence of two spotted mite in jasmine intercropped with marigold is 15.37 per cent with a 30.67 percent reduction over jasmine sole crop. The intercrop with more efficacies falling next in the order was gingelly recording $28.41,18.69,13.36$, $11.47,12.69$ and 14.52 per cent incidence with a mean incidence of 16.52 per cent. Coriander crop intercropped in jasmine field also had potential in minimizing two spotted mite incidence recording 26.20, 19.40, 14.36, $12.25,14.35$ and 15.69 per cent incidence with a mean incidence of 17.04 per cent. The order falls as clusterbean $>$ onion $>$ cowpea $>$ black gram fenugreek $>$ fennel. Among the intercrops examined, jasmine + fennel recorded maximum two spotted mite incidence ( 19.26 per cent), followed by jasmine+fenugreek (18.27 per cent) indicating their poor efficiency in repelling the pest (Figure 1).

Table I Incidence of two spotted mite, Tetranychus urticae in jasmine ecosystem as influenced by intercrops

\begin{tabular}{|c|c|c|c|c|c|c|c|c|c|}
\hline \multirow{2}{*}{$\begin{array}{l}\text { T. } \\
\text { No. }\end{array}$} & \multirow{2}{*}{$\begin{array}{l}\text { Intercropping } \\
\text { system }\end{array}$} & \multicolumn{6}{|c|}{ Percent incidence* } & \multirow{2}{*}{ Mean } & \multirow{2}{*}{ PROC } \\
\hline & & 20 DAS & 30 DAS & 40 DAS & 50 DAS & 60 DAS & 70 DAS & & \\
\hline $\mathrm{T}_{\mathrm{I}}$ & Jasmine+Cowpea & $17.33(4.16)$ & $13.00(3.60)^{b}$ & $11.66(3.4 I)^{b c}$ & $12.33(3.5 \mathrm{I})^{\mathrm{bc}}$ & $15.33(3.91)^{b}$ & $17.6(4.20)^{b}$ & $13.99(3.74)^{c}$ & 21.09 \\
\hline $\mathrm{T}_{2}$ & Jasmine+Black gram & $18.00(4.23)$ & $12.00(3.46)^{b}$ & $13.33(3.64)^{\mathrm{abc}}$ & $14.66(3.82)^{a b}$ & $15.33(3.91)^{b}$ & $17.00(4.1 \mathrm{I})^{\mathrm{b}}$ & $14.46(3.80)^{\mathrm{b}}$ & 18.44 \\
\hline $\mathrm{T}_{3}$ & $\begin{array}{l}\text { Jasmine+Cluster } \\
\text { bean }\end{array}$ & I8.66 (4.32) & $13.32(3.35)^{b}$ & $12.33(3.5 \mathrm{I})^{\mathrm{bc}}$ & $14.00(3.74)^{\mathrm{abc}}$ & $15.66(3.95)^{b}$ & $16.33(4.04)^{c}$ & $14.32(3.78)^{\mathrm{b}}$ & 19.18 \\
\hline $\mathrm{T}_{4}$ & Jasmine+Coriander & $20.33(4.50)$ & $13.33(3.64)^{b}$ & $10.66(3.26)^{c}$ & $13.33(3.64)^{b c}$ & $16.66(4.07)^{b}$ & $17.33(4.16)^{b}$ & $14.26(3.77)^{b}$ & 19.96 \\
\hline $\mathrm{T}_{5}$ & Jasmine+Fenugreek & I8.33 (4.28) & $13.00(3.60)^{b}$ & $13.33(3.65)^{\mathrm{ab}}$ & $15.00(3.87)^{\mathrm{ab}}$ & $16.33(4.04)^{b}$ & $18.00(4.24)^{b}$ & $15.13(3.89)^{b}$ & 14.66 \\
\hline $\mathrm{T}_{6}$ & Jasmine+Gingelly & $17.33(4.16)$ & $12.33(3.5 \mathrm{I})^{\mathrm{b}}$ & $12.00(3.46)^{\mathrm{bc}}$ & $14.00(3.74)^{\mathrm{ab}} \mathrm{c}$ & $15.66(3.95)^{b}$ & I $6.00(4.00)^{\mathrm{b}}$ & $13.99(3.74)^{c}$ & 21.04 \\
\hline $\mathrm{T}_{7}$ & Jasmine+Fennel & I $6.66(4.08)$ & $13.33(3.65)^{b}$ & $14.33(3.78)^{\mathrm{ab}}$ & $15.00(3.87)^{\mathrm{ab}}$ & $16.66(4.08)^{b}$ & $17.00(4.12)^{b}$ & $15.26(3.90)^{b}$ & 13.9 \\
\hline $\mathrm{T}_{8}$ & Jasmine+Onion & $17.33(4.15)$ & II.33 (3.36) & $11.00(3.31)^{c}$ & $12.33(3.50)^{b c}$ & $13.00(3.60)^{c}$ & $15.00(3.87)^{c}$ & $12.53(3.53)^{c}$ & 29.32 \\
\hline $\mathrm{T}_{9}$ & Jasmine+Marigold & I $6.66(4.08)$ & $12.00(3.46)^{b}$ & $10.66(3.26)^{c}$ & $11.33(3.36)^{c}$ & I3.00 (3.60) & $14.66(3.82)^{c}$ & $12.33(3.5 I)^{c}$ & 30.45 \\
\hline$T_{10}$ & Jasmine sole crop & $18.00(4.23)$ & $17.33(4.15)^{\mathrm{a}}$ & $16.33(4.03)^{\mathrm{a}}$ & $17.00(4.11)^{\mathrm{a}}$ & $18.33(4.27)^{\mathrm{a}}$ & $19.66(4.42)^{\mathrm{a}}$ & I7.73 (4.20) ${ }^{\mathrm{a}}$ & \\
\hline \multicolumn{2}{|l|}{ SE } & & 0.1916 & 0.1874 & 0.1967 & 0.2081 & 0.2168 & 0.2004 & \\
\hline
\end{tabular}

NS-non significant; *Mean of three replications, DAS, days after sowing

NS-non significant; *Mean of three replications, DAS, days after sowing

Figures in parentheses are square root transformed values in a column, means followed by common letter(s) are not significantly different by LSD (P=0.05)

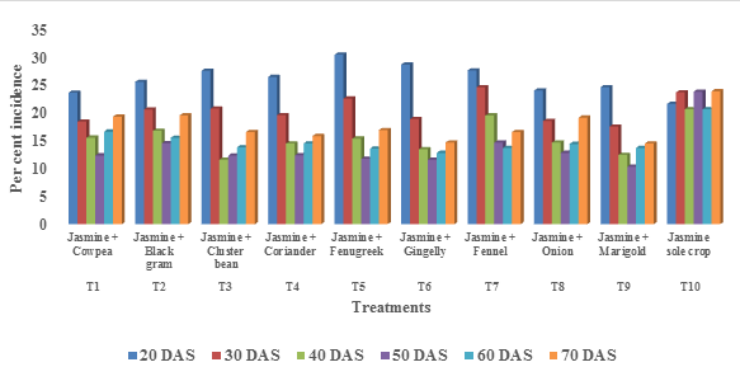

Figure IA Incidence of two spotted mite of jasmine intercropping system.

\section{Incidence of natural enemies in intercropping system Impact of intercrops on coccinellid population}

The mean population of coccinellids (Cheilomenes sexmaculatus, Coccinella transversalis, Brumus sutularis, Scymnus sp.,) in various intercropping systems ranged from 8.70 nos. $/ 5$ plants (jasmine+marigold) to 3.2 nos. $/ 5$ plants (jasmine + fennel) (Table

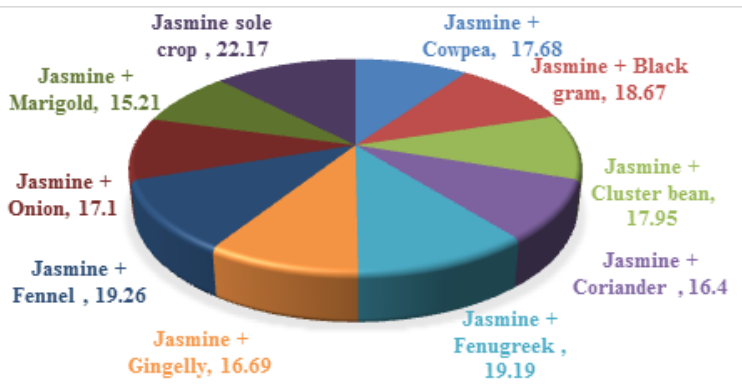

Figure IB Mean incidence of two spotted mite of jasmine intercropping system.

2) while it was 1.10 nos. $/ 5$ plants in jasmine pure crop. The mean population of coccinellids was higher (from 8.70 nos./5 plants) in jasmine intercropped with marigold which was on par statistically with jasmine + cowpea (7.50 nos./5 plants). Jasmine intercropped with fennel, gingelly and cluster bean recorded least coccinellid population (3.2, 3.6, 3.7 no's/5 plants) (Plate 1) (Plate 2). 


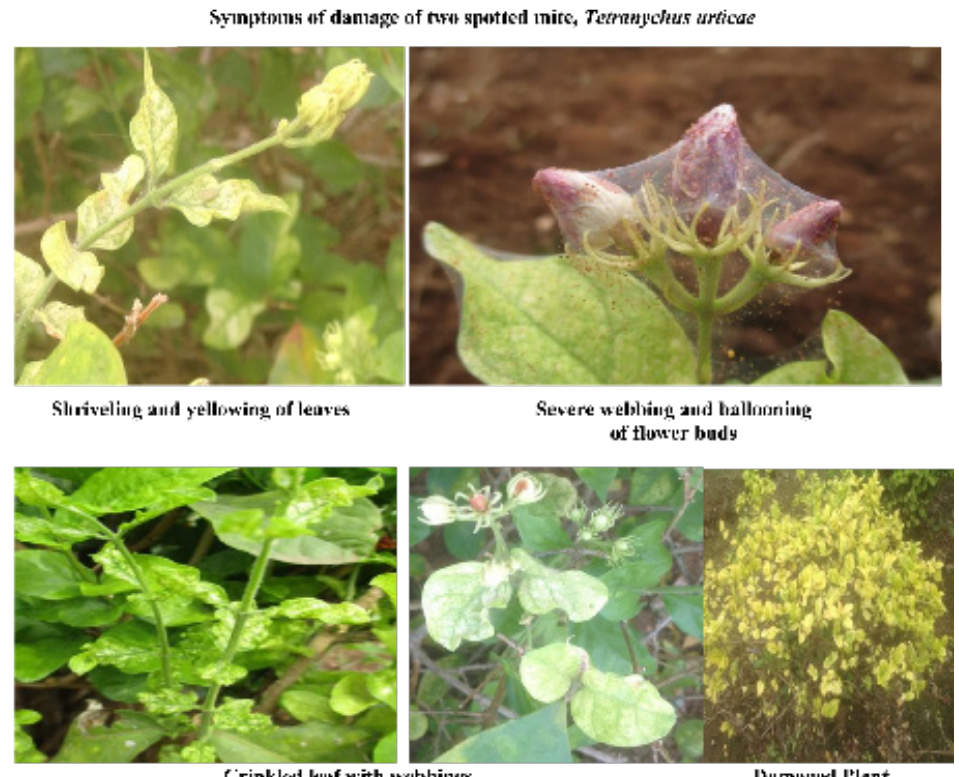

Crinkled leaf with ncbbingrs

1).magetel P'lant
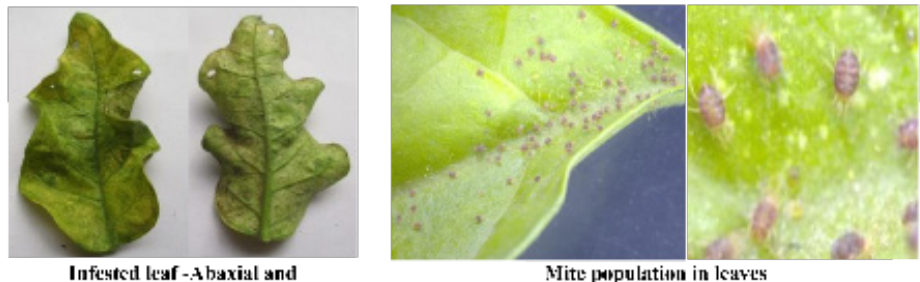
indasial sitle

Plate I Damage symptoms of jasmine two spotted mite, Tetranychus urticae.

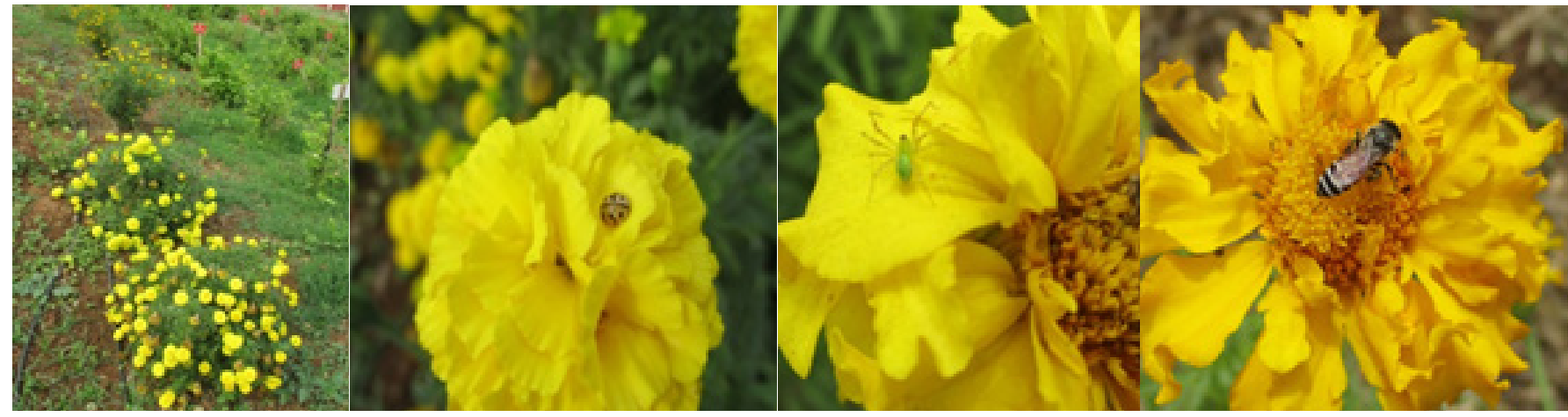

Plate 2 Natural enemies in marigold intercropped in jasmine.

Table 2 Incidence of natural enemies in jasmine ecosystem as influenced by intercrops

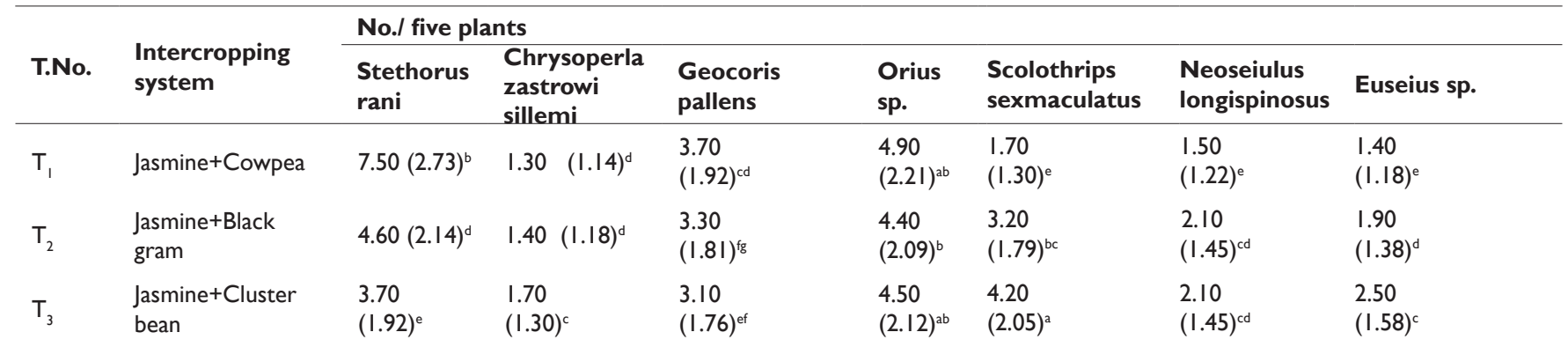

Citation: Kamala IM. Crop diversification for sustainable management of two spotted mite (Tetranychus urticae koch) of jasmine (Jasminum sambac L.). Horticult Int J. 20 I9;3(2):46-53. DOI: I0.15406/hij.20 I9.03.00 I I I 
(Table 2 continue...)

\begin{tabular}{|c|c|c|c|c|c|c|c|c|}
\hline $\mathrm{T}_{4}$ & Jasmine + Coriander & $4.90(2.21)^{d}$ & $\begin{array}{l}3.50 \\
(1.87)^{\mathrm{a}}\end{array}$ & $\begin{array}{l}3.50 \\
(1.87)^{\mathrm{de}}\end{array}$ & $\begin{array}{l}4.80 \\
(2.19)^{\mathrm{ab}}\end{array}$ & $\begin{array}{l}3.40 \\
(1.84)^{\mathrm{bc}}\end{array}$ & $\begin{array}{l}2.30 \\
(1.51)^{b}\end{array}$ & $\begin{array}{l}1.10 \\
(1.05)^{f}\end{array}$ \\
\hline$T_{5}$ & Jasmine+Fenugreek & $\begin{array}{l}4.90 \\
(2.21)^{d}\end{array}$ & $\begin{array}{l}1.90 \\
(1.38)^{c}\end{array}$ & $\begin{array}{l}2.90 \\
(1.70)^{g}\end{array}$ & $\begin{array}{l}4.90 \\
(2.21)^{\mathrm{ab}}\end{array}$ & $\begin{array}{l}2.30 \\
(1.52)^{\mathrm{de}}\end{array}$ & $\begin{array}{l}1.80 \\
(1.34)^{c}\end{array}$ & $\begin{array}{l}1.10 \\
(1.05)^{f}\end{array}$ \\
\hline$T_{6}$ & Jasmine+Gingelly & $\begin{array}{l}3.60 \\
(1.89)^{\mathrm{e}}\end{array}$ & $\begin{array}{l}2.50 \\
(1.58)^{\mathrm{ab}}\end{array}$ & $\begin{array}{l}4.20 \\
(2.05)^{b}\end{array}$ & $\begin{array}{l}5.40 \\
(2.32)^{\mathrm{a}}\end{array}$ & $\begin{array}{l}4.60 \\
(2.14)^{\mathrm{a}}\end{array}$ & $\begin{array}{l}2.30 \\
(1.5 I)^{b}\end{array}$ & $\begin{array}{l}3.20 \\
(1.79)^{\mathrm{b}}\end{array}$ \\
\hline $\mathrm{T}_{7}$ & Jasmine+Fennel & $\begin{array}{l}3.20 \\
(1.79)^{f}\end{array}$ & $\begin{array}{l}1.30 \\
(1.14)^{d}\end{array}$ & $\begin{array}{l}2.70 \\
(1.64)^{g}\end{array}$ & $\begin{array}{l}4.30 \\
(2.07)^{\mathrm{b}}\end{array}$ & $\begin{array}{l}1.90 \\
(1.38)^{\mathrm{e}}\end{array}$ & $\begin{array}{l}1.60 \\
(1.26)^{\mathrm{cd}}\end{array}$ & $\begin{array}{l}1.30 \\
(1.14)^{\mathrm{e}}\end{array}$ \\
\hline $\mathrm{T}_{8}$ & Jasmine+Onion & $\begin{array}{l}6.10 \\
(2.47)^{c}\end{array}$ & $2.30(\mathrm{I} .5 \mathrm{I})^{\mathrm{ab}}$ & $\begin{array}{l}3.90 \\
(1.97)^{b c}\end{array}$ & $\begin{array}{l}5.10 \\
(2.25)^{\mathrm{ab}}\end{array}$ & $\begin{array}{l}3.10 \\
(1.76)^{\mathrm{bc}}\end{array}$ & $\begin{array}{l}2.40 \\
(1.55)^{b}\end{array}$ & $\begin{array}{l}1.30 \\
(1.14)^{\mathrm{e}}\end{array}$ \\
\hline$T^{9}$ & Jasmine+Marigold & $\begin{array}{l}8.70 \\
(2.95)^{\mathrm{a}}\end{array}$ & $3.60(1.90)^{\mathrm{a}}$ & $\begin{array}{l}4.40 \\
(2.10)^{\mathrm{a}}\end{array}$ & $\begin{array}{l}5.30 \\
(2.30)^{\mathrm{a}}\end{array}$ & $\begin{array}{l}4.30 \\
(2.07)^{\mathrm{a}}\end{array}$ & $\begin{array}{l}2.60 \\
(1.61)^{\mathrm{a}}\end{array}$ & $\begin{array}{l}3.60 \\
(1.89)^{\mathrm{a}}\end{array}$ \\
\hline$T_{10}$ & Jasmine sole crop & $\begin{array}{l}1.10 \\
(1.05)^{\mathrm{e}}\end{array}$ & $0.20 \quad(0.45)^{f}$ & $\begin{array}{l}0.20 \\
(0.45)^{\mathrm{h}}\end{array}$ & $\begin{array}{l}1.30 \\
(1.14)^{c}\end{array}$ & $\begin{array}{l}1.20 \\
(1.09)^{f}\end{array}$ & $\begin{array}{l}1.20 \\
(1.09)^{a}\end{array}$ & $\begin{array}{l}0.20 \\
(0.45)^{8}\end{array}$ \\
\hline SE & & 0.1032 & 0.0819 & 0.0622 & 0.0972 & 0.0745 & 0.0777 & 0.0615 \\
\hline $\mathrm{CD}(0.05)$ & & 0.2169 & 0.1722 & 0.1306 & 0.2043 & 0.2147 & 0.1632 & 0.1524 \\
\hline
\end{tabular}

*Mean of three replications, DAS: Days after sowing; Figures in parentheses are square root transformed values. In a column, means followed by common letter(s) are not significantly different by LSD $(\mathrm{P}=0.05)$

\section{Impact of intercrops on chrysoperla zastrowi sillemi (esben- peterson) population}

Jasmine intercropped with marigold recorded the highest mean population of $C$. zastrowi sillemi (3.60 nos./5 plants), followed by jasmine+coriander (3.50 nos./5 plants) which was on par with jasmine intercropped with gingelly ( 2.50 no's. $/ 5$ plants) and onion ( 2.30 no's $/ 5$ plants) (Table 2). The C. zastrowi sillemi mean population of 1.30 no's/5 plants were recorded in jasmine intercropped with fennel and cowpeas, respectively, while it was 0.20 no's $/ 5$ plants in jasmine pure crop recording the least incidence.

\section{Impact of intercrops on preying mantids' population}

The mean population of preying mantids was highest in jasmine intercropped with marigold (4.40 no,s/5 plants) followed by jasmine intercropped with gingelly, onion and cowpea registering 4.20, 3.90 and 3.70 no's $/ 5$ plants as against 0.20 no's $/ 5$ plants in jasmine sole crop (Table 2).

\section{Impact of intercrops on spider population}

Jasmine intercropped with marigold recorded maximum spider population of (5.30 no's/5 plants), but there was no significant difference noticed among various intercropping systems on spider population, with the least population being recorded in jasmine sole crop (1.30 no's/5 plants) (Table 2).

Impact of intercrops on the predator, Systatsis dasyneurae population

The mean emergence of the predator, Systasis dasyneurae from fifty infested jasmine buds collected from jasmine intercropped with marigold was 4.30 no's/fifty infested buds, registering the maximum population as against 1.20 no's/fifty infested buds in jasmine sole crop (Table 2). Jasmine intercropped with sesamum recorded 4.60 no's/fifty infested buds, and Jasmine intercropped with cliuster bean recorded 4.20 no's/fifty infested buds, Jasmine intercropped with fennel and fenugreek (1.90 and 2.30 no's/five plants) registered the least parsitoid emergence among the intercrops examined (Figure 2).

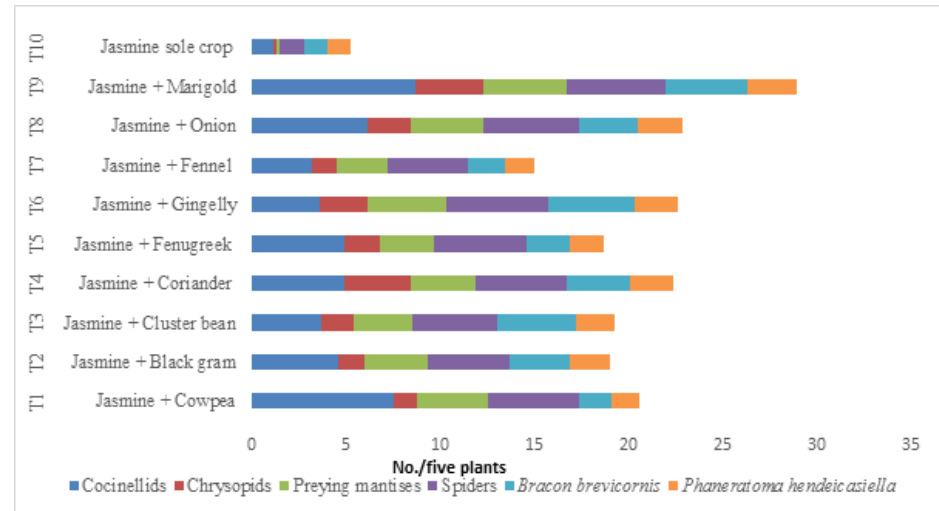

Figure $\mathbf{2}$ Incidence of natural enemies in jasmine intercropping system. 


\section{Pest defender ratio}

The total number of pests (all the insects and mites with the potential to damage the plant) and natural enemies (all the natural enemies observed including coccinellids, chrysopids, preying mantises, spiders, Systasis dasyneurae, Geocoris bugs, larval parasitoids, Bracon brevicornis, Phanerotoma hendecasiella) were recorded in all the jasmine based intercropping systems and pest defender ratio was worked out.

The highest population of pests was recorded in jasmine intercropped with fenugreek, blackgram and cowpea (11.33, 9.33 and 7.33 no's/5 plants). The least population of pests in intercrops was observed in fenugreek and coriander (no pest) and highest in jasmine intercropped with cowpea and blackgram (5.33 and 4.66 no's/5 plants) (Table 3).

Table 3 Total number of pests and natural enemies in intercropping system

\begin{tabular}{|c|c|c|c|c|c|c|c|c|}
\hline \multirow[b]{2}{*}{ T.No. } & \multirow[b]{2}{*}{$\begin{array}{l}\text { Intercropping } \\
\text { system }\end{array}$} & \multicolumn{6}{|c|}{ No./plant } & \multirow[b]{2}{*}{ P:D ratio } \\
\hline & & $\begin{array}{l}\text { Pests in } \\
\text { jasmine }\end{array}$ & $\begin{array}{l}\text { Pests in } \\
\text { intercrops }\end{array}$ & Total pests & $\begin{array}{l}\text { Natural } \\
\text { enemies in } \\
\text { jasmine }\end{array}$ & $\begin{array}{l}\text { Natural } \\
\text { enemies in } \\
\text { intercrops }\end{array}$ & $\begin{array}{c}\text { Total natural } \\
\text { enemies } \\
\text { (Defenders) }\end{array}$ & \\
\hline $\mathrm{T}_{\mathrm{I}}$ & Jasmine+Cowpea & $8.33(2.70)^{c}$ & $5.33(2.28)^{d}$ & $13.66(3.69)^{\mathrm{e}}$ & $4.33(2.08)^{c}$ & $10.33(3.21)^{b}$ & $14.66(3.82)^{\mathrm{de}}$ & I:I.07 \\
\hline $\mathrm{T}_{2}$ & Jasmine+Black gram & $7.33(2.58)^{\mathrm{bc}}$ & $4.66(2.06)^{d}$ & II.99 (3.46) & $2.66(1.63)^{d}$ & $9.66(3.10)^{c}$ & $12.32(3.50)^{\mathrm{ef}}$ & $\mathrm{I}: 1.03$ \\
\hline $\mathrm{T}_{3}$ & $\begin{array}{l}\text { Jasmine }+ \text { Cluster } \\
\text { bean }\end{array}$ & $6.66(2.5 \mathrm{I})^{\mathrm{ab}}$ & $1.66(1.21)^{b c}$ & $8.32(2.88)^{\mathrm{cd}}$ & $5.33(2.31)^{b}$ & I3.66 (3.69) & $18.99(4.35)^{\mathrm{bc}}$ & $\mathrm{I}: 2.28$ \\
\hline $\mathrm{T}_{4}$ & Jasmine + Coriander & $6.33(3.05)^{\mathrm{ab}}$ & $0.00(0.00)^{\mathrm{a}}$ & $6.33(2.5 \mathrm{I})^{\mathrm{ab}}$ & $5.66(2.37)^{b}$ & $13.66(3.69)^{\mathrm{a}}$ & $19.32(4.39)^{\mathrm{ab}}$ & $\mathrm{I}: 3.05$ \\
\hline $\mathrm{T}_{5}$ & Jasmine+Fenugreek & $9.33(2.58)^{c}$ & $0.00(0.00)^{\mathrm{a}}$ & $9.33(3.05)^{d}$ & $2.33(1.53)^{d}$ & $8.66(2.94)^{d}$ & $10.99(3.31)^{f}$ & $\mathrm{I}: 1.18$ \\
\hline $\mathrm{T}_{6}$ & Jasmine+Gingelly & $6.66(3.65)^{\mathrm{ab}}$ & $1.33(1.10)^{b c}$ & $7.99(2.82)^{\mathrm{bcd}}$ & $5.33(2.3 \mathrm{I})^{\mathrm{b}}$ & I3.33 $(3.65)^{\mathrm{a}}$ & $18.66(4.32)^{\mathrm{bc}}$ & $\mathrm{I}: 2.34$ \\
\hline $\mathrm{T}_{7}$ & Jasmine+Fennel & $11.33(3.36)^{d}$ & $0.33(0.53)^{\mathrm{ab}}$ & $13.66(3.69)^{e}$ & $3.66(I .9 \mid)^{\mathrm{cd}}$ & $10.33(3.21)^{b}$ & I3.99 (3.74) de & I:I.02 \\
\hline $\mathrm{T}_{8}$ & Jasmine+Onion & $6.00(2.45)^{\mathrm{a}}$ & $1.33(1.19)^{\mathrm{ab}}$ & $7.33(2.70)^{\mathrm{abc}}$ & $4.33(2.08)^{\mathrm{bc}}$ & I I.33 (3.36) & $15.66(3.95)^{\mathrm{cd}}$ & $\mathrm{I}: 2.14$ \\
\hline $\mathrm{T}_{9}$ & Jasmine+Marigold & $5.33(2.30)^{\mathrm{a}}$ & $0.66(0.80)^{\mathrm{ab}}$ & $5.99(2.44)^{\mathrm{a}}$ & $6.33(2.5 \mathrm{I})^{\mathrm{a}}$ & I4.66 (3.82) & $20.99(4.58)^{\mathrm{ab}}$ & $\mathrm{I}: 3.50$ \\
\hline
\end{tabular}

**NS, non significant; **each value is the mean of three replications, DAS, days after sowing; Figures in parentheses are square root transformed values. In a column, means followed by common letter(s) are not significantly different by LSD $(P=0.05)$

The total number of pests in jasmine and intercrops was more in jasmine + cowpea and jasmine + fennel intercropping system, recording 13.33 no's/ 5 plants and the least number being in jasmine+marigold, jasmine + onion and jasmine + gingelly $(5.99,6.33$ and 9.33 no's/ 5 plants). Among all the nine intercrops evaluated, the total natural enemy population was more in jasmine+marigold (20.99 no's/5 plants), followed by jasmine+ clusterbean (18.99 no's/5 plants) and jasmine+gingelly (18.66 no's/5 plants). The pest defender ratio was highest in jasmine+marigold (1:3.50) and the order falls as jasmine+coriander (1:3.05) and jasmine+gingelly (1:2.34). The ratio was least recorded in jasmine + fennel $(1: 1.02)$ and jasmine+fenugreek $(1: 1.18)$ intercropping systems (Figure 3$)$

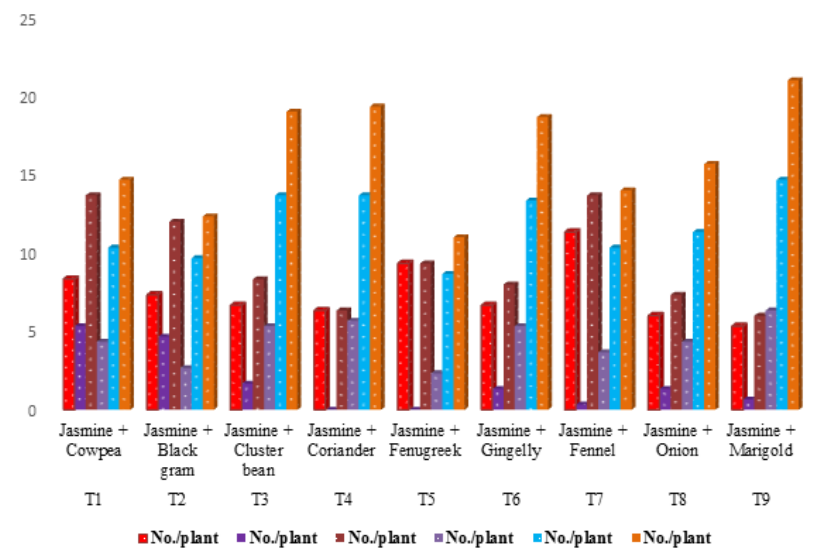

Figure 3 Pests and natural enemy incidence in sole and jasmine intercrops.
Marygold attracted lot of natural enemies and bagged the credit of ecofeast crop. Jasmine intercropped with marigold recorded the highest mean population of coccinellids (Cheilomenes sexmaculatus, Coccinella transversalis, Brumus suturalis, Scymnus sp., (8.70 no's. $/ 5$ plants), C. z. sillemi (3.60 nos. $/ 5$ plants), preying mantises (4.40 nos $/ 5$ plants) and spider population ( 5.30 nos. $/ 5$ plants). The mean emergence of the specific midge predator, Systasis dasyneurae from jasmine intercropped with marigold was highest (4.30 no's./50 infested buds). Among all the nine intercrops evaluated, the total natural enemy population was more in jasmine +marigold (20.99 no's/ five plant) recording highest pest defender ratio (1:3.50).

\section{Discussion}

Pest outbreaks are rare in polyculture condition due to the ability of the diverse plant culture to self-sustain through natural pest control by increasing the occurrence of natural enemies. ${ }^{12,13}$ Polyculture offers alternate prey or hosts and alternate food sources such as pollen and nectar. ${ }^{14}$ Polycultures that support high densities of natural enemies might have increased incidence of predation and parasitization of herbivores. Diverse environmental conditions would provide a greater diversity of habitats and victims to predators and parasitoids through time as well as alternate food sources such as pollen and nectar, ${ }^{15}$ and so sustain more stable populations of natural enemies than monocultures.

The present study identified marigold as the eco-feast crop by reducing two spotted mite incidence and increasing natural enemy population. The present result endorsed the findings of Sujayanand et al. ${ }^{9}$ who reported that intercropping of eggplant with marigold is a successful strategy for reducing the fruit and shoot borer and 
sucking pest especially jassids and whiteflies. Marigolds have been shown promising results in companion planting (Hooks et al). ${ }^{16}$ Marigolds have been shown to behave as natural pest deterrents by secreting the toxic chemical $\alpha$-terthienyl through their roots and thus fending of surrounding threats. ${ }^{17}$ Additionally, they give off a very pungent odour, which is thought to detract most above ground insects. ${ }^{18}$ Density of phytophagous insects on non-marigold plants were less noticed as being reduced by more than 50 per cent when grown in close proximity to Tagetus patula. ${ }^{19}$ Allelochemicals emanated from the intercrop might be responsible to repel the herbivores in jasmine ecosystem, as pointed out by Gomez et al. ${ }^{20}$ who reported that volatile allelochemicals are exuded from aerial parts of marigold (Tagetes erecta L.). When intercropped with tomato, marigold suppressed, repelled and changed the oviposition behaviour of insect pests by more than 90 per cent. Allelopathic effect of marigold in pest management was supported by Farooq et al. ${ }^{6}$ The findings emerged from the present study is supported by Lakshminarayanan et al. ${ }^{8}$ who explicated that raising intercrops in jasmine ecosystem recorded less incidence of pests with additional income in yield.

Intercropping has been reported to reduce insect pest populations due to deterrence in crop fields with increased plant diversity that creates unsuitable habitat or unfavourable environment to pest species. ${ }^{21}$ Intercropping particularly with four row of jasmine to one row of marigold developed less population of sucking and lepidopteran infestations

The present results are in agreement with the findings of Silveria et al. who reported marigold as a plant that is potentially useful to maintain arthropod biodiversity. Additionally, marigold plants inbetween rows of onion crop have been shown to promote the reduction of aphid, nematode and whitefly populations and virus diseased plants. ${ }^{22}$ Moreover, marigold plants host other phytophagous species that are alternative prey for entomophagous species. Some organic growers raise marigold for its pollen and nectar, which increase natural enemy fecundity and survival. ${ }^{23}$

Research works on intercropping to manage dipterans are very scarce. Dhawan et al. ${ }^{24}$ corroborated that sorghum intercropped with leguminous plants has reduced sorghum shoot fly (Contarinia sorghicola) incidence. Paul and david ${ }^{25}$ confirmed that shootfly incidence was greatly reduced by intercrop [[ing sorghum with legumes.

Sujayanand et al. ${ }^{9}$ confirmed the results of the present study that marigold in brinjal ecosystem attracted natural enemies and checked the shoot and fruit borer naturally. Kennedy et al. ${ }^{4}$ endorsed that intercropping groundnut with pearl millet favoured the predators and parasites of groundnut insect pests. Duffield and Reddy ${ }^{26}$ reported an increased activity of coccinellids and spiders in leguminous intercrops. The migratory nature of ladybird beetles was shown by Lin et al. ${ }^{27}$ in China, when cotton intercropped with alfalfa which attracted greater number of ladybird beetles, lacewings and spiders, when alfalfa was cut to force migration of natural enemies to cotton. Hanumantharaya et al. ${ }^{28}$ also found that intercrop of cotton with lucerne@1:1 ratio increased the effectiveness of green lacewings. A rich diversity in predatory insect and parasitoid species was recorded from intercropping system like groundnut + maize and groundnut + bajra wherein intercrop supplied pollen and nectar as supplementary feed to the natural enemies. ${ }^{29}$ This supplementary food resource increases the parasitoid fecundity, longevity ${ }^{30}$ and also favours rapid colonization of generalist predators. ${ }^{31}$
To identify the compounds responsible for the repellence of pests and attraction of natural enemies, the marigold flower and leaf extracts were analyzed in GC-MS. The chemical profile of marigold flower and leaf extracts contributed 43 and 33 compounds respectively. Allyl iso thiocyanate, linalool, caryophyllene, beta myrcene, tumerone, D-limanone and trans beta ocimene were the compounds of interest present, of which, linalool, beta farnesene, alpha farnesene, allyl isothiocyanate and caryophyllene were present in marigold leaves also.Chemically complex plant volatiles have multiple ecological roles in plant-insect interactions including attracting pollinators, acting as cues for foraging herbivores as well as functioning as direct defense, indirect defense, or interplant priming. Caryophyllene is an active component of marigold flowers and leaves and its potential in attracting two types of herbivore enemies viz., entomopathogenic nematodes and parasitic wasps in maize ecosystem was demonstrated by Kollner et al..$^{32}$ The chemical fraction containing (E)- $\beta$-caryophyllene attracts egg parasitoid, Trissolcus basalis of $\mathrm{s}$ that parasitizes Nezara viridula eggs. ${ }^{33,34}$ Comparing the compounds present in marigold leaves and flowers, 9 compounds were present in common viz., allyl isothiocyanate, detected twice, linalool, beta myrcene, L-limanone, caryophyllene, thiopene, beta ocimene, eugenol, tetracosane, tricosane, pentacosane, heneicosane and bis $(2$ ethyl hexyl phthalate) with quantity in abundance in marigold flowers (Figure 4). ${ }^{35}$

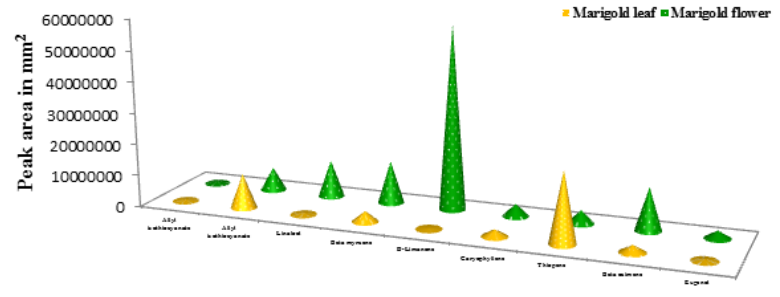

Figure 4A Comparison of the common hydrocarbons presents in marigold (Tagetus erecta) .

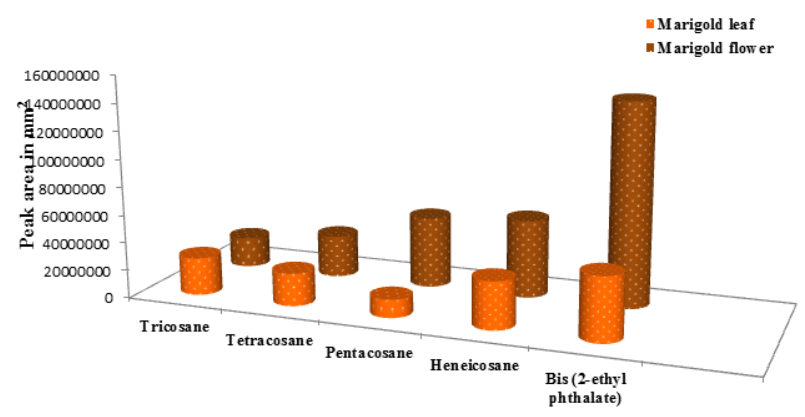

Figure 4B Comparison of the common hydrocarbons present in marigold (Tagetus erecta) flower and leaf).

There is an increasing interest in plant volatile compounds and its implications in pest management, as they can directly influence insect behaviour. The study suggested that the plant biodiversity is an important factor that influences the presence of pests as well as natural 
enemies influencing the former negatively and the latter positively. Thus, habitat manipulations could be used to reduce two spotted mite incidence and conserve natural enemies in jasmine ecosystem.

\section{Acknowledgment}

The financial assistance provided by UGC, fellowship to pursue Ph.D. in Agricultural Entomology at Tamil Nadu Agricultural University, Coimbatore is gratefully acknowledged for the senior author.

\section{Conflicts of interest}

The author declares there is no conflicts of interest.

\section{References}

I. Thakur A, Naqvi SMA, Aske DK, et al. Study of some ethno medicinal plants used by tribals of Alirajpur, Madhya Pradesh, India. Res J Agriculture and Forestry Sci. 2014;2(4):9-12.

2. Ray H, Majumdar S, Biswas SP, et al. Characterization of the volatile aroma compounds from the concrete and jasmine flowers grown in India. Chemical engineering transactions. 2014;40:265-270.

3. Nimisha Suryavanshi, Razia Parvez. Production of rose and marigold flower in Allahabad city. Res J Agriculture and Forestry Sci. 20 I4;2(9): I-3.

4. Kennedy FJS, Balaguranathan R, Christopher A, et al. Insect pest management in peanut: a cropping system approach. Tropical Agric. |997;7|(2): | |6-I I8.

5. Halagundagowda N, Nagaraja MS, Meenakshi HK. Statistical analysis on factors influencing on shift in cropping patterns in different agro-climatic zones of Karnataka. The Bioscan. 2015; 10(3):1395-1399.

6. Farooq M, Jabran K, Cheema ZA, et al.The role of allelopathy in agricultural pest management. Pest Management Science. 20I I;67(5):493-506.

7. Altieri MA, Letourneau DK.Vegetation management and biological control in agroecosystems. Food Products Press. New York. 1982;261.

8. Lakshminarayanan M, Hari Priya K, Manivannan K, et al. Evaluation of leguminous vegetables as intercrops in pruned fields of jasmine (Jasminum sambac L.). Journal of spices and aromatic crops. 2005; I4(I):6I-64.

9. Sujayanand GK, Sharma RK, Shankarganesh K, et al. Crop diversification for sustainable insect pest management in eggplant. Florida Entomologist. 2015;98(I):305-314.

10. Anburani A, Priyadharshini HV. Response of yield parameters and profitability of mullai to intercropping system (Jasminum auriculatum). The Asian Journal of Horticulture. 201 I;6(I):26-28.

II. Lokesh S, Muthukrishnan N, Ganapathy N, et al. Ecological engineering cropping methods enhance Coccinellids and suppress aphids Aphis gossypii (Glover) in blackgram. Journal of Entomology and Zoology Studies. 2017;5(3):1288-1294.

12. Altieri MA. Biodiversity and pest management in agroecosystems. Food products press, New York; 1994:275.

13. Scherr SJ, McNeely JA. Biodiversity conservation and agricultura sustainability: Towards a new paradigm of 'ecoagriculture' landscapes. Philosophical Transactions of the Royal Society. USA. 2008;477.

14. Root R. Organisation of a plant-arthropod association in simple and diverse habitats. The fauna of collards (Brassica oleracea L.). Ecol Monogr. 1973;43:93-124.

15. Van Emden HF. The effect of uncultivated land on the distribution of cabbage aphid on an adjacent crop. J Appl Ecol. 1965;2 I7I-196.
16. Hooks CR, Wang $\mathrm{KH}$, Ploeg A, et al. Using marygolds as cover crops to protect plants from plant parasitic nematodes. Applied soil ecology. 2010;46:307-320.

17. Gommers FJ, J Bakker. Physiological changes induced by plant responses or products. Diseases of nematodes. 1988; 1:4.

18. Parker JE, Snyder WE, Hamilton GC, et al. Companion planting in insect pest control-Conventional and new challenges. In Tech. 2013.

19. Silveira L, Filho E, Pierre L, et al. Marigold (Tagetus erecta as an attractive crop to natural enemies in onion fields. Scientia Agricola. 2009;66:6.

20. Gomez-R, Hern A, Andez VA, et al. Allelopathy and microclimatic modification of intercropping with marigold on pest management. Field Crops Res. 2003;83:27-34.

21. Khan ZR,Ampong NK, Chiliswa P, et al. Intercropping increases parasitism of pests. Nature. 1997;388:63I-632.

22. Abid M, Magbool M. Effects of inter-cropping of (Tagetes erecta) on rootknot disease and growth of tomato. International Nematology Network Newsletter. 1990;7:41-42.

23. Baggen LR, Meats A, Gurr GM. Flowers in tri-trophic systems: mechanisms allowing selective exploitation by insect natural enemies for conservation biological control. Entomologia Experiementalis et Applicata. 1999;91:155161 .

24. Dhawan AK, Singh, Balwinder, et al. Integrated Pest management. Scientific Publishers. 2013;494.

25. Paul D, R David. Biological control by natural enemies. Cambridge University Press. 1991.

26. Duffield SJ, Reddy YV. Distribution and increment of predators of Helicoverpa armigera in intercropped sorghum and short duration pigeonpea. Crop Research. 1997; 14:3 I5-335.

27. Lin R, Liang $\mathrm{H}$, Zhang $\mathrm{R}$, et al. Impact of alfalfa / cotton intercropping and management on some aphid predators in China. J. Appl. Entomol. 2003; I27(I):33-36.

28. Hanumantharaya L, Basavannagoud K, Krishnanaik L. Use of green lacewing, Chrysoperla carnea (Stephens) and neem seed kernel extract for management of insect pests of cotton. Kar JAgric Sci. 2008;2 I (I):4 I-44.

29. Bianchi FJJ, Booij A,Tscharntke T. Sustainable pest regulation in agricultural landscapes: a review on landscape composition, biodiversity and natural pest control. Proceedings of the Royal Society. 2006;273:1715-1727.

30. Tylianakis, JM, Didham RK, Wratten SD. Improved fitness of aphid parasitoids receiving resource subsidies. Ecology. 2004;85 658-666.

31. Symondson WOC, Sunderland KD, Greenstone MH. Can generalist predators be effective biocontrol agents. Ann Review Entomol. 2002;47:56 I594.

32. Kollner TG, Held M, Lenk C, et al. A Maize (E)- $\beta$-Caryophyllene Synthase implicated in indirect defense responses against herbivores is not expressed in most American maize varieties. Plant Cell. 2008;20(2):482494.

33. Colazza ML, Bue D, Giudice L, et al. The response of Trissolcus basalis to footprint contact kairomones from Nezara viridula females is mediated by leaf epicuticular waxes. Naturwissenschaften. 2009;96:975-981.

34. Colazza S, Mcelfresh JS, Miller JG. Identification of volatile synomones, induced by Nezara viridula feeding and oviposition on Bean spp., that attract the egg parasitoid, Trissolcus basalis Journal of Chemical Ecology. 2004;30(5):945-964.

35. Gunasekaran V.Studies on bio-ecology of jasmine pest complex. M.Sc (Ag) Thesis, Tamil Nadu Agric. University, Coimbatore; 1989. 